\author{
Tugas Akhir \\ Prodi Manajemen Fakultas Ekonomi \\ Universitas Andi Djemma
}

\title{
Pengaruh Tingkat Suku Bunga terhadap Pemberian Kredit Briguna (kredit pegawai) pada PT. Bank Rakyat Indonesia (persero) Tbk Unit Sidomukti
}

\begin{abstract}
Andi Mariam
(Program studi Manajemen Fakultas Ekonomi Unversitas Andi Djemma, Email: andi.mariam@gmail.com)
\end{abstract}

Pembimbing: Nurjannah, S.E., M.M \& Didi Haryono, S.Si., M.Si

\begin{abstract}
Abstrak
Tujuan penelitian ini adalah untuk mengetahui pengaruh tingkat suku bunga terhadap pemberian kredit Briguna (kredit pegawai) pada PT. Bank Rakyat Indonesia (persero) Tbk Unit Sidomukti. Kegiatan penelitian dilaksanakan pada PT. Bank Rakyat Indonesia (persero) Tbk Unit Sidomukti, Kec. Bone-Bone, Kab. Luwu Utara. Penelitian ini dilaksanakan selama dua bulan terhitung dari bulan Februari sampai dengan bulan April 2020. Pengambilan sampel menggunakan teknik purposive sampling yaitu teknik pengambilan sampel berdasarkan kriteriakriteria tertentu yang akan dijadikan sebagai bahan pertimbangan dalam pemilihan sampel. Simpulan dari penelitian ini adalah variabel Tingkat Suku Bunga (X) berpengaruh terhadap Pemberian Kredit Briguna (Y) pada Bank Rakyat Indonesia (persero) Tbk, Unit Sidomukti Kec. Bone-Bone, Kab. Luwu Utara, pengaruh tersebut dapat dilihat pada tabel koefisien hasil regresi yang menunjukkan nilai signikannya sebesar 0,037 lebih kecil dari 0,05 atau 0,037<0,05, artinya hipotesis diterima. Besarnya pengaruh atau kontribusi dari variabel bebas dapat dilihat dari nilai $\mathrm{R}$ Square sebesar 0,812. Hal ini berarti bahwa kemampuan variabel tingkat suku bunga memberikan kontribusi terhadap variabel Pemberian Kredit Briguna pada Bank Rakyat Indonesia (Persero) Tbk, Unit Sidomukti, Kec. Bone-Bone, Kab. Luwu Utara sebesar $81,2 \%$, sedangkan 18,88\% dipengaruhi variabel lain yang tidak diteliti.
\end{abstract}

Kata Kunci: Tingkat suku bunga, pemberian kredit.

\section{Pendahuluan}

Sejarah perbankan mengacu pada perkembangan bank dan perbankan sepanjang sejarah, dengan istilah perbankan yang ditetapkan oleh sumber-sumber kontemporer sebagai sebuah organisasi yang menyediakan fasilitas untuk penerimaan simpanan dan pemberian kredit. Wujud awal bank adalah para pedagang yang memberikan pinjaman biji-bijian kepada para petani dan pedagang yang membawa barang-barang antara kota. Hal ini dimulai sekitar tahun $2000 \mathrm{SM}$ di Asyur dan Sumeria. Kemudian, di Yunani kuno dan selama Kekaisaran 
Romawi, pemberi pinjaman yang bertempat di kuil-kuil memberikan pinjaman, menerima simpanan dan melakukan pertukaran uang. Arkeologi dari periode ini di Cina kuno dan India juga menunjukkan bukti kegiatan peminjaman uang. Banyak catatan sejarah yang menempatkan posisi penting sejarah perkembangan sistem perbankan pada Italia abad pertengahan dan Renaisans dan khususnya kota-kota penting seperti Florensia, Venesia, dan Genoa. Keluarga Bardi dan Peruzzi mendominasi perbankan abad ke-14 di Florence, mendirikan cabang-cabang di berbagai tempat di Eropa. Bank Italia yang paling terkenal adalah bank Medici, yang didirikan oleh Giovanni Medici pada tahun 1397. Salah satu bank tertua yang masih berdiri adalah Banca Monte dei Paschi di Siena, yang berkantor pusat di Siena, Italia, dan telah beroperasi terus menerus sejak 1472.

Perkembangan perbankan menyebar dari Italia utara ke seluruh Kekaisaran Romawi Suci, dan pada abad ke-15 dan abad ke-16 ke Eropa utara. Hal ini diikuti oleh sejumlah inovasi penting yang berlangsung di Amsterdam selama Republik Belanda pada abad ke-17, dan di London sejak abad ke-18. Selama abad ke-20, perkembangan di bidang telekomunikasi dan komputasi menyebabkan perubahan besar pada pola kegiatan bank dan menjadikan bank-bank meningkat secara ukuran, jumlah dan penyebaran geografis. Krisis keuangan 2007-2008 menyebabkan banyak kegagalan bank, termasuk beberapa bank terbesar di dunia, dan memicu banyak perdebatan tentang peraturan bank yang berdampak pada peningkatan jumlah pengangguran akibat pemutusan kerja para pegawai (Didiharyono \& Syukri, 2020).

Di era globalisasi ini, hampir semua negara menaruh perhatian besar terhadap bank karena juga memiliki peranan strategis bagi penguatan ketahanan ekonomi suatu negara sebagai sumber keuangan atau modal pengusaha. Terjadinya pelarian modal keluar negeri (capital fight) bukan hanya merupakan dampak merosotnya nilai rupiah atau tinginya inflasi dan rendahnya suku bunga disuatu negara. Tetapi karena tidak tersediahnya alternatif investasi yang menguntungkan dinegara tersebut atau pada saat yang sama, investasi portofolio dibursa negara lain menjanjikan keuntungan yang jauh lebih tinggi. Keadaan ini menjadi konsekuensi dari terbukanya pasar saham terhadap investor asing (Kasse dkk, 2019) (Kasse, dkk, 2021). 
Seperti halnya di Indonesia, bank mulai muncul pada abad ke-18 dan sampai sekarang masih berkembang. Di Indonesia terdapat berbagai jenis bank salah satunya yaitu PT. Bank Rakyat Indonesia. PT. Bank Rakyat Indonesia didirikan pada 16 Desember 1895 di Purwokerto dan beroperasi hingga saat ini dan memiliki banyak cabang dan unit yang tersebar di berbagai wilayah di Indonesia salah satunya yaitu PT. bank Rakyat Indonesia Unit Sidomukti yang beralamat di jln. Trans Sulawesi, Desa Patoloan, Kec. Bone-bone, Kab.Luwu utara, didirikan pada tahun 1982. PT. Bank Rakyat Indonesia (Persero) Tbk Unit Sidomukti menyediakan berbagai produk kredit yang menawarkan kemudahan bagi masyarakatt, mulai dari kredit tanpa agungan, kredit pemilikan rumah tangga, sampai kredit pemilikan bermotor. Berbagai produk pinjaman ini dihadirkan dengan bunga yang kompetitif sehingga masyarakat sering kali merasa terbantu sebab pinjaman dari bank, dan sebagian dari masyarakat membayar kredit ada yang lancar dan ada juga yang macet, sehingga suku bunga bank sangat berperan penting dalam pengkreditan, Salah satu masalah dalam angsuran kredit pada PT. Bank Rakyat Indonesia (Persero) Tbk Unit sidomukti disebabkan karna adanya debitur yang ingin berpindah ke lembaga keuanggan yang lain dan ingin peluanasan sebelum jatuh tempo pada waktu yang ditentukan maka pihak bank akan memberikan finalti ( tiga angsuran) kepada nasabah tersebut.

Suku bunga merupakan jumlah uang yang dibayarkan sebagai imbalan atau penggunaan yang dipinjam. Bagi bank, bunga merupakan komponen pendapatan yang paling tinggi. Dari total pendapatan yang diterima bank, sebagian besar diperoleh dari bunga pinjaman. Suku bunga yang tinggi akan dapat menimbulkan tingginya volume tabungan masyarakat. Makin tinggi tingkat suku bunga yang ditawarkakn bank mendorong masyarakat untuk lebih banyak menabung, artinya , masyarakat cenderung akan mengurangi konsumsinya guna menambah saldo tabungan yang dimiliki. Selain itu, suku bunga yang tinggi akan berdampak melonjaknya biaya modal perusahaan., sehingga perusahaan akan mengalami persaingan dalam investasi, artinya para investor cenderung memilih berinvestasi ke pasar uang atas tabungan dibandingkan pasar modal.

Berikut tabel tingkat suku bunga dan jumlah nasabah pada PT. Bank Rakyat Indonesia (Persero) Tbk, Unit Sidomukti, Kec. Bone-Bone, Kab. Luwu Utara 
[ 56] Fatma, Artikel Ilmiah (Tugas Akhir), Prodi Manajemen Fakultas Ekonomi Unanda

\begin{tabular}{|c|c|c|}
\hline Tahun & Jumlah Nasabah (Aktif) & Suku Bunga / Tahun \\
\hline 2015 & 31 & $16,50 \%$ \\
\hline 2016 & 90 & $13,90 \%$ \\
\hline 2017 & 90 & $13,50 \%$ \\
\hline 2018 & 118 & $12 \%$ \\
\hline 2019 & 180 & $12,50 \%$ \\
\hline
\end{tabular}

Pada tabel di atas tingkat suku bunga setiap tahunnya mengalami penurunan hal ini karna kebijakan pemerintah dalam mengatur suku bunga salah satu alasannya agar penurunan suku bunga untuk mendorong pertumbuhan ekonomi dalam negeri yang melambat, dengan menurunnya tingkat suku bunga bank maka jumlah debitur semakin meningkat karena rendahnya tingkat suku bunga dan kebutuhan konsumtif masyarakat juga meningkat.

\section{Metode}

Kegiatan penelitian dilaksanakan pada PT. Bank Rakyat Indonesia (persero) Tbk Unit Sidomukti, Kec. Bone-Bone, Kab. Luwu Utara. Penelitian ini dilaksanakan selama dua bulan terhitung dari bulan Februari sampai dengan bulan April 2020. Pengambilan sampel menggunakan teknik purposive sampling yaitu teknik pengambilan sampel berdasarkan kriteria-kriteria tertentu yang akan dijadikan sebagai bahan pertimbangan dalam pemilihan sampel. Sampel-sampel dalam penelitian ini harus berdasarkan kriteria sebagai berikut :

a. Nasabah yang aktif dan terdaftar di PT. Bank Rakyat Indonesia (Persero) Tbk. Unit Sidomukti dengan periode antara tahun 2015 sampai 2019.

b. Nasabah kredit pegawai PT. Bank Rakyat Indonesia kantor Unit Sidomukti, dimana nasabah tersebut yang memiliki pekerjaan sebagai pegawai tetap.

Berdasarkan kriteria sampel tersebut peneliti melakukan uji pada populasi tersebut yakni terdapat 6 sasaran nasabah pada PT. Bank Rakyat Indonesia kantor Cabang Unit Sidomukti yang akan digunakan dalam penelitian ini, antara lain Pegawai Negeri Sipil (PNS) pusat dan daerah, Anggota Tentara Negara Indonesia (TNI), Anggota Kepolisian Negara Republik Indonesia (Polri), Pegawai Badan 
Usaha Milik Negara (BUMN), Pegawai Badan Usaha Milik Daerah (BUMD), dan Pegawai Perusahaan Swasta.

\section{Hasil dan Pembahasan}

\subsection{Hasil penelitian}

1. Penyaluran Kredit Briguna

Kredit kepada pegawai tetap / pensiunan yang diberikan kepada calon debitur / debitur dengan sumber pembayaran yang berasal dari sumber penghasilan tetap / fixed income (gaji / uang pensiun). Adapun jumlah kredit Briguna yang disalurkan PT. Bank Rakyat Indonesia (Persero) Tbk Unit Sidomukti Kec. Bone-Bone, Kab. Luwu Utara pada kurun waktu 2015-2019 adalah sebagai berikut :

Tabel 1. Jumlah Kredit Briguna

\begin{tabular}{|c|l|c|l|}
\hline Tahun & \multicolumn{1}{|c|}{ Jumlah Kredit } & $\begin{array}{c}\text { Suku Bunga / } \\
\text { Tahun }\end{array}$ & $\begin{array}{c}\text { Jumlah Pendapatan dari } \\
\text { Bunga/Tahun }\end{array}$ \\
\hline 2015 & Rp 2.963.100.000 & $16,50 \%$ & Rp 488.911.500 \\
\hline 2016 & Rp 10.677.600.000 & $13,90 \%$ & Rp 1.484.186.400 \\
\hline 2017 & Rp 10.807.200.000 & $13,50 \%$ & Rp 1.458.972.000 \\
\hline 2018 & Rp 16.694.000.000 & $12 \%$ & Rp 2.003.280.000 \\
\hline 2019 & Rp 25.923.400.000 & $12,50 \%$ & Rp 3.240.425.000 \\
\hline
\end{tabular}

Sumber : Data PT. Bank Rakyat Indonesia (Persero)Tbk, Unit Sidomukti

\section{Analisis Data}

a. Analisis Regresi Linier Sederhana

Analisis regresi liniear sederhana adalah hubungan secara linear antara satu variabel independen $(\mathrm{X})$ dengan variabel dependen (Y). Analisis ini bertujuan untuk mengetahui arah hubungan antara variabel independen dengan variabel dependen apakah positif atau negatif, dan untuk memprediksi nilai variabel independen mengalami kenaikan atau penurunan.

Analisis ini digunakan untuk menghitung besarnya pengaruh tingkat Suku Bunga (X) terhadap Pemberian Kredit Briguna (Y). Untuk mempermudah dalam perhitungannya maka data dari tabel 1 di ubah dalam bentuk Logaritma Natural (LN) sebagai berikut :

Dependent Variable: pemberian 
Tabel 2. Data LN

\begin{tabular}{|c|c|c|c|}
\hline NO & $\begin{array}{c}\text { TINGKAT SUKU } \\
\text { BUNGA }(\mathrm{X}) \\
\%\end{array}$ & $\begin{array}{c}\text { PEMBERIAN KREDIT } \\
(\mathrm{Y})\end{array}$ & LN \\
\hline 1 & 16.50 & 2.963 .100 .000 & 21,8095 \\
\hline 2 & 13.90 & 10.677 .600 .000 & 23,09141 \\
\hline 3 & 13.50 & 10.807 .200 .000 & 23,10348 \\
\hline 4 & 12.00 & 16.694 .000 .000 & 23,53832 \\
\hline 5 & 12.50 & 25.923 .400 .000 & 23,97841 \\
\hline
\end{tabular}

Berdasarkan pembahasan masalah dan hipotesis yang telah dikemukakan

Sebelumnya maka didapat hasil pengolahan data dengan menggunakan software

SPSS 20 yang tampak pada tabel 3 :

\begin{tabular}{|c|c|c|c|c|c|c|}
\hline \multicolumn{7}{|c|}{ Coefficients $^{\mathrm{a}}$} \\
\hline & \multirow[b]{2}{*}{ Model } & \multicolumn{2}{|c|}{ Unstandardized Coefficients } & \multirow{2}{*}{$\begin{array}{c}\text { Standardized } \\
\text { Coefficients } \\
\text { Beta } \\
\end{array}$} & \multirow[b]{2}{*}{$\mathrm{T}$} & \multirow[b]{2}{*}{ Sig. } \\
\hline & & B & Std. Error & & & \\
\hline & (Constant) & 28.899 & 1.764 & & 16.385 & .000 \\
\hline 1 & & & & -.901 & & .037 \\
\hline
\end{tabular}

a. Dependent Variable: pemberian kredit

kredit briguna

Dari tabel 1 diperoleh persamaan sebagai berikut :

$\mathrm{Y}=\mathrm{a}+\mathrm{bx}$

$\mathrm{Y}=28.899-460 \mathrm{X}$

Dan persamaan tersebut dapat diartikan :

a. Konstanta (a)

Konstanta sebesar 28..899 mengandung arti bahwa nilai konsisten variabel

Pemberian Kredit Briguna adalah sebesar 28.899. 
b. Nilai koefisien untuk variabel tingkat suku bunga (X) sebesar -460 . Hal ini mengandung arti bahwa setiap kenaikan variabel Tingkat Suku Bunga (X) satu satuan maka variabel pemberian Kredit Briguna (Y) akan men galami penurunan sebesar 460 satuan. Koefisien regresi tersebut bernilai negatif, sehingga dapat dikatakan bahwa arah pengaruh variabel $\mathrm{X}$ terhadap Y adalah negatif.

3. Pengujian Hipotesis

a. Uji T

Uji ini digunakan untuk mengetahui apakah variabel-variabel Independen secara persial berpengaruh nyata atau tidak terhadap variabel Dependen. Derajat signifikan yang digunakan adalah 0,05 .

\begin{tabular}{|c|c|c|c|c|c|c|}
\hline \multicolumn{7}{|c|}{ Coefficients $^{a}$} \\
\hline \multirow{2}{*}{\multicolumn{2}{|c|}{ Model }} & \multicolumn{2}{|c|}{ Unstandardized Coefficients } & \multirow{2}{*}{$\begin{array}{c}\begin{array}{c}\text { Standardized } \\
\text { Coefficients }\end{array} \\
\text { Beta }\end{array}$} & \multirow[b]{2}{*}{$\mathrm{T}$} & \multirow[b]{2}{*}{ Sig. } \\
\hline & & $\mathrm{B}$ & Std. Error & & & \\
\hline \multirow[t]{2}{*}{1} & (Constant) & 28.899 & 1.764 & & 16.385 & .000 \\
\hline & tingkat suku bunga & -.460 & .128 & -.901 & -3.595 & .037 \\
\hline
\end{tabular}

a. Dependent Variable: pemberian krı

- Terlihat bahwa pada variabel X dan variabel Y nilai sigfinikansi sebesar $0,037<0,05$ sehingga dapat disimpulkan bahwa variabel Tingkat Suku Bunga (X) berpengaruh terhadap variabel Pemberian Kredit Briguna (Y) dan berdasarkan nilai $\mathrm{T}$ diketahui nilai $\mathrm{T}$ hitung $3.595>\mathrm{T}$ tabel 3,184 artinya hipotesis diterima, sehingga dapat disimpulkan bahwa variabel Tingkat Suku Bunga (X) berpengaruh terhadap pemberian kredit Briguna (Y).

Cara mencari $t_{\text {tabel }}$

$$
\begin{aligned}
& \mathrm{df}=\mathrm{n}-\mathrm{k}-1 \\
& \mathrm{df}=5-1-1 \\
& \mathrm{df}=3
\end{aligned}
$$

b. Koefisien Determinasi $\left(R^{2}\right)$

Dari harga koefisien korelasi kita dapat menentukan harga koefisien determinasi $\left(R^{2}\right)$ yang berguna untuk mengetahui besarnya persentase 
kontribusi variabel independen terhadap variabel dependen (M. Nazir, 2011:460)

\begin{tabular}{|c|r|r|r|r|}
\hline \multicolumn{1}{|c|}{ Model Summary } \\
Model & $\mathrm{R}$ & $\mathrm{R}$ Square & $\begin{array}{c}\text { Adjusted R } \\
\text { Square }\end{array}$ & $\begin{array}{c}\text { Std. Error of the } \\
\text { Estimate }\end{array}$ \\
\hline 1 & $.901 \mathrm{a}$ & .812 & .749 & .44828 \\
\hline
\end{tabular}
a. Predictors: (Constant), tingkat suku bunga $(x)$
b. Dependen variabel, (y)

Setelah $\mathrm{r}_{\text {hitung }}$ diketahui sebesar 0,901 maka selanjutnya untuk mengetaui seberapa besar pengaruh variabel $\mathrm{X}$ terhadap variabel $\mathrm{Y}$ dengan menggunakan koefisien determinan $R^{2}$ yang dinyatakan dalam persentase.

Hasilnya sebagai berikut :

$$
\begin{aligned}
R^{2} & =(0,901)^{2} \times 100 \% \\
& =811,801 \times 100 \% \\
& =811 \% \text { dibulatkan }(812 \%)
\end{aligned}
$$

Dari hasil perhitungan di atas maka dapat disimpulkan bahwa nilai $\mathrm{R}$ Square yaitu 0,812 hal ini berarti kemampuan variabel Tingkat Suku Bunga memberikan konstribusi teradap Pemberian Kredit Briguna pada PT. Bank Rakyat Indonesia, dengan kata lain dapat disimpulkan bahwa variabel Tingkat Suku Bunga berpengaruh sebesar 81,2 \% terhadap Pemberian Kredit Briguna pada Bank Rakyat Indonesia (Persero) Tbk, Unit Sidomukti, Kec. Bone-Bone, Kab. Luwu Utara, sedangkan 18,88\% dipengaruhi variabel lain yang tidak diteliti.

\subsection{Pembahasan}

Tingkat Suku Bunga ber pengaruh Terhadap Pemberian Kredit Briguna dengan menggunakan prinsip-prinsip pemberian kredit yang benar maka akan menciptakan keuntungan yang besar pula kepada PT. Bank Rakyat Indonesia (Persero) Tbk, Unit Sidomukti, Kec.Bone-Bone, Kab.Luwu Utara dan tujuan yang diinginkan dapat tercapai. Pemberian kredit merupakan sumber utama pendapatan bagi PT. Bank Rakyat Indonesia (Persero) Tbk, Unit Sidomukti, Kec.Bone-Bone, 
Kab.Luwu Utara dengan kinerja yang baik dan pemberian kredit yang lancar kepada masyarakat.

Pemberian kredit bank haruslah berhati-hati, pemberian kredit kepada pelanggan atau nasabah dilakukan berdasarkan analisa pemberian kredit, analisa kelayakan pemberian kredit kepada nasabah pada dasarnya adalah memperkirakan kemampuan nasabah dalm mengelolah usahanya sehingga akan dapat membayar kewajibannya. Hal tersebut dapat dilakukan dengan menerapkan prinsip-prinsip umum pemberian kredit, menganalisa berkas dokumen dan catatan nasabah, mencari masukan dari sumber-sumber lain, misalnya daftar hitam penunggak kredit, kelompok usaha yang sejenis, mitra usaha pelanggan.

Hasil penelitian ini sejalan dengan penelitian yang dilakukan oleh Haris (2001) dengan hasil yaitu bahwa Tingkat Suku Bunga berpengaruh signifikan dan positif terhadap Pemberian Kredit dan variabel yang paling dominan berpengaruh adalah tingkat suku bunga.

Penelitian ini juga didukung oleh penelitian sebelumnya yang dilakukan oleh Wati (2013) menunjukkan bahwa jika suku bunga Bank berpengaruh terhadap Pemberian Kredit Pinjaman.

Berdasarkan hasil penelitian ini menemukan pengaruh fignifikan negatif antara Tingkat Suku Bunga dengan Pemberian Kredit Briguna yang menunjukkan nilai signikannya sebesar 0,037 dan lebih kecil dari 0,05 atau $0,037<0,05$.

\section{Kesimpulan}

Simpulan dari penelitian ini adalah variabel Tingkat Suku Bunga (X) berpengaruh terhadap Pemberian Kredit Briguna (Y) pada Bank Rakyat Indonesia (persero) Tbk, Unit Sidomukti Kec. Bone-Bone, Kab. Luwu Utara, pengaruh tersebut dapat dilihat pada tabel koefisien hasil regresi yang menunjukkan nilai signikannya sebesar 0,037 lebih kecil dari 0,05 atau 0,037<0,05, artinya hipotesis diterima. Besarnya pengaruh atau kontribusi dari variabel bebas dapat dilihat dari nilai $\mathrm{R}$ Square sebesar 0,812 . Hal ini berarti bahwa kemampuan variabel tingkat suku bunga memberikan kontribusi terhadap variabel Pemberian Kredit Briguna pada Bank Rakyat Indonesia (Persero) Tbk, Unit Sidomukti, Kec. Bone-Bone, Kab. Luwu Utara sebesar 81,2\%, sedangkan 18,88\% dipengaruhi variabel lain yang tidak diteliti. 
Berdasarkan hasil penelitian yang dilakukan bahwa Tingkat Suku Bunga berpengaruh signifikan negatif terhadap Pemberian Kredit Briguna, maka disarankan agar Bank Rakyat Indonesia (Persero) Tbk, Unit Sidomukti, Kec. Bone-Bone, Kab. Luwu Utara untuk memperhatikan Tingkat Suku Bunga karna pada hasil penelitian ini setiap kenaikan Tingkat Suku Bunga satu satuan maka dalam Pemberian Kredit Briguna akan mengalami penurunan karna suku bunga yang naik, hal ini dapat memberikan dampak pada pemberian kredit itu sendiri, sehingga keinginan masyarakat untuk mengambil kredit menjadi semakin kecil karna beban bunga yang dibayar juga semakin tinggi, selain itu kenaikan Tingkat suku Bunga dapat menimbulkan penurunan jumlah konsumsi dan jumlah produksi sebab perusahaan (instansi) akan mengurangi jumlah pinjaman modal dari bank, bahkan cenderung untuk tidak melakukan pinjaman dana, sehingga hal tersebut dapat menyebabkan penurunan laba pada PT. Bank Rakyat Indonesia Unit Sidomukti.

\section{Daftar Pustaka}

Haryono Jusup. (2005). Dasar-Dasar Akuntansi, Yogyakarata, BPPE Yogyakarta.

Andika Ika Fahrika, (2016). Pengaruh Tingkat Suku Bunga Melalui Investasi Swasta Terhadap Pertumbuhan Ekonomi, Jurnal Ecces Ekonomi, Social, And Development Studies, Vol.3 No.2. Desember 2016.

Ayom Gumelar, Bayu. (2013). "Pengaruh Inflasi, Tingkat Suku Bunga Deposito, Dan Jumlah Bagi Hasil Deposito Terhadap Jumlah Deposito Muḍarabah Studi Kasus PT Bank Syariah Mandiri Tahun 2008-2012.Skripsi. Jakarta: UIN Syarif Hidayatullah.

Barus, A.C. dan Marya Lu. (2012). Pengaruh spread Tingkat Suku Bunga Dan Rasio Keuangan Terhadap Penyaluran Kredit UMKM Pada Bank Umum Di Indonesia. Jurnal Wira Ekonomi Mikroskil Volume 3, Nomor 01, April 2013. STIE Mikroskil Medan.

Didiharyono, D., \& Syukri, M. (2020). Forecasting with arima model in anticipating open unemployment rates in south sulawesi. Int. J. Sci. Technol. Res, 9(3), 3838-3841.

Irwan, I., \& Haryono, D. (2015). Pengendalian Kualitas Statistik (Pendekatan Teoritis dan Aplikatif). Bandung, Alfabeta

Janah, L. (2016). "Pengaruh Inflasi, Tingkat Bagi Hasil, Ukuran Perusahaan, Dan Financing Deposit To Ratio (FDR) Terhadap Jumlah Deposito Mudharabah Pada Bank Umum Syariah Di Indonesia Periode 2011 2015”. Skripsi.Jakarta : UIN Syarif Hidayatullah. 
[63] Fatma, Artikel Ilmiah (Tugas Akhir), Prodi Manajemen Fakultas Ekonomi Unanda

Kadir, K. (2016). Statistik Terapan : Konsep, Contoh dan Analisis Data dengan Program SPSS/Lisrel dalam Penelitian. Jakarta: Rajawali Pers.

Karl dan Fair, (2001). Pengertian suku bunga, Edisi pertama, Cetakan Pertama, Kencana, Jakarta

Kasse, I., Didiharyono, D., \& Maulidina, M. (2019). Metode Markov Chain untuk Menghitung Premi Asuransi pada Pasien Penderita Penyakit Demam Berdarah Dengue. Al-Khwarizmi: Jurnal Pendidikan Matematika dan Ilmu Pengetahuan Alam, 7(2), 151-160.

Kasse, I., Mariani, A., Utari, S., \& Didiharyono, D. (2021). Investment Risk Analysis On Bitcoin With Applied of VaR-APARCH Model. JTAM (Jurnal Teori dan Aplikasi Matematika), 5(1), 1-13.

Kasmir. (2016). Bank dan Lembaga Keuangan Lainnya Edisi Revisi. Jakarta : Rajawali Pers.

Martono, Nanang. (2014). Metode penelitian Kuantitatif: Analisis Isi dan Analisis Data Sekunder Edisi Revisi 2. Jakarta : PT. Rajawali Pers.

Puspitaningrum, R., et. al. (2014). Pengaruh Tingkat Inflasi, Tingkat Suku Bunga

SBI, dan Pertumbuhan Ekonomi Terhadap Nilai Tukar Rupiah (Studi pada Bank Indonesia Periode Tahun 2003-2012), Jurnal Administrasi Bisnis (JAB) Vol.8 No.1 Februari 2014.

Rahmadhania, Nur. (2016). Pengaruh Suku Bunga, Inflasi, Bagi Hasil Dan Likuiditas Terhadap Jumlah Simpanan Deposito MudharabahPada Bank Muamalat Indonesia Periode 2011-2015”. Skripsi.Yogyakarta:UIN Sunan Kalijaga.

Saputra, Eri \& Santoso, Bambang Hadi. (2017). Pengaruh Nilai Tukar Mata Uang, Inflasi, dan Suku Bunga Terhadap Harga Saham Sektor Properti, Jurnal Ilmu dan Riset Manajemen Vol.6 No.5.

Sinaga, Asmawarna. (2016). "Analisis Pengaruh Tingkat Suku Bunga (BI Rate), Bagi Hasil, Inflasi Dan Harga Emas Terhadap Jumlah Deposito Muḍarabah Perbankan Syariah Periode 2010-2015”. (Analytica Islamica, Vol. 5, No. 2, 2016: 315-341).

Sugiono, Arief dan Untung, Edy. (2008). Panduan Praktis Dasar Analisa Laporan Keuangan: Pengetahuan Dasar Bagi Mahasiswa Dan Praktisi Perbankan. Jakarta: Grasindo

Suhartini, E. (2012). Kualitas pelayanan kaitannya dengan kepuasan konsumen. Alauddin University Press, Makasssar

Tandris, Raimond, P Tommy, S. Murni. (2014). Suku Bunga, Inflasi dan Nilai Tukar Pengaruhnya Terhadap Permintaan Kredit Perbankan Di Kota Manado. Jurnal EMBA Vol.2 No.1 Maret 2014, Hal.244.

Zamzami. (2017). “Analisis Pengaruh Bagi Hasil, Inflasi, SWBI dan BI Rate Terhadap Tabungan MudharabahPada Perbankan Syariah Periode 20102014". Tesis. Medan: Universitas Islam NegeriSumatera Utara. 